\title{
A survey on electric/hybrid vehicles
}

\author{
Bernardo RIBEIRO, Francisco P BRITO, Jorge MARTINS \\ Dep. Mechanical Engineering, Universidade do Minho, Portugal
}

Copyright $\odot 2010$ SAE International

\begin{abstract}
Since the late 19th century until recently several electric vehicles have been designed, manufactured and used throughout the world. Some were just prototypes, others were concept cars, others were just special purpose vehicles and lately, a considerable number of general purpose cars has been produced and commercialized.
\end{abstract}

Since the mid nineties the transportation sector emissions are being increasingly regulated and the dependency on oil and its price fluctuations originated an increasing interest on electric vehicles $(\mathrm{EV})$.

A wide research was made on existing electric/hybrid vehicle models. Some of these vehicles were just in the design phase, but most reached the prototype or full market production. They were divided into several types, such as NEVs, prototypes, concept cars, and full homologated production cars. For each type of vehicle model a technical historic analysis was made. Data related to the vehicle configuration as well as the embedded systems were collected and compared. Based on these data future prospect of evolution was subsequently made.

The main focus was put on city vehicles and long range vehicles. For city vehicles the market approach normally consists in the use of full electric configuration while for the latter, the hybrid configuration is commonly used. The electrical systems and combustion engines found in these vehicles are compared in order to forecast the evolution trend in terms of specifications and performance of the whole vehicle and of each system.

\section{INTRODUCTION}

Environment policy measures are being implemented worldwide aiming at the reduction of emissions of greenhouse gases and other pollutants from the transportation sector. This sector is one of the major $\mathrm{CO} 2$ emitter and road vehicles constitute the main pollutant sources in cities. Furthermore, vehicles with internal combustion engines are noisy, therefore increasing the level of noise pollution. With this in mind, several locations in the world (e.g. London [1]) are introducing policies for the establishment of electric fleets, by offering electrical connection (recharging) for electric vehicles and other advantages such as free parking and no access restriction to inner city areas. These measures resulted in the increasing trade and use of electric vehicles. At the moment it is possible to buy a variety of vehicles, from small NEV (neighborhood electric vehicles) to large delivery vans, obviously including sedan vehicles and even sports cars. Electric vehicles are produced in various locations in the world, with emphasis to North America, Europe, Japan and recently in China ([2]).

Following the nomenclature used by SAE, [3,4] an electric vehicle is a vehicle in which its propulsion is accomplished entirely by electric motors only, regardless for the means of obtaining that electric energy. Therefore, what previously was known as a series hybrid vehicle, is now referred to as an electric vehicle, and Page 1 of 26 
the expression "hybrid car" is only used for parallel hybrid systems. At the same time, the internal combustion engine used by "series hybrid" to produce electricity within the car is now known by the term "range extender". In this category lie vehicles using internal combustion engines (turbines included) and fuel cells, as these produce electricity from a fuel such as hydrogen.

Electric cars rely on lead-acid batteries as the energy source for locomotion since the end of the 19th century. These batteries were outdated by the NiMH and Li-ion types, but in terms of the price/energy ratio, lead batteries still rule. Therefore it is common to find lead-acid batteries on the lower priced electric cars. Another conventional disadvantage of batteries is their low power, which is not sufficient to allow for proper brake recovery. These extremely high powers cannot be supplied to batteries but they may be given to supercapacitors or ultracapacitors. Therefore, the use of supercapacitors combined with batteries would allow a strong increase of the potential for braking energy recovery, while additionally extending the life of the batteries, filtering the electric peaks. Lately, innovative nano-materials applied to lithium based batteries $[5,6]$ and carbon based supercapacitors [7] are surfacing, having properties that extend significantly the range of operation of common Li-ion batteries and supercapacitors, enabling huge power for the batteries and significant energy storage for the capacitors. But on the whole, storage is still the major hurdle in the mass production and use of electric cars, as the energy density of batteries is orders of magnitude away from that of liquid fuels.

Electricity, within the vehicle can also be produced by thermal engines (gasoline or Diesel IC engines, gas turbines or other types) or by any type of fuel cells. In such cases the range of the vehicle is achieved by the batteries plus the range provided by the use of the fuel stored in the car.

The energy sources for the thermal engines or fuel cells may vary, from fossil fuels (gasoline, diesel, LPG, NG) to biofuels (biodiesel, alcohols, biogas), or synthetic fuels (Fischer Tropsch fuels), and includes the energy carrier hydrogen. Batteries are a form of chemical storage, but it is possible to use mechanical storage devices, such as flywheels [8]. Recently, Formula 1 cars started using energy storage devices known as KERS (kinetic energy recovery system) that enable cars to recover part of the braking energy and use it during acceleration [9].

Cars with internal combustion engines always use transmission systems to connect the engine to the wheels and a differential in order to allow both wheels to have different speeds when cornering. Electric cars seldom use these devices, as each power wheel may be connected to one electric motor. Furthermore, the speed of each motor can be that of the corresponding wheel, therefore eliminating the need for transmission and gears. When this happens the rotation of the motor is the same of the revolving wheel, which usually is somehow small (1 $500 \mathrm{rpm}$ max), leading to slow rotating electric motors. However, electric motors can have a much better power/weight ratio than internal combustion engines, mainly if they achieve high speed ( 15 $000 \mathrm{rpm})$. For lower speeds, electric motors have a lower power/weight ratio but can be installed inside the driving wheel with obvious advantages of packaging [10]. Some cars have the motors connected to the wheels through driveshafts and gears, while others use just one electric motor connected to a differential in the conventional layout.

Electric cars and hybrids with internal combustion engines tend to use higher efficiency cycles, such as overexpanded cycles for spark ignition combustion type. This cycle, also known as Miller or Atkinson, has the particularity of having the expansion longer that the compression, leading to a higher expansion of the burned gases, therefore achieving a higher efficiency. [11]. Hybrid vehicles rely on the IC engine as the main propulsion system, being the electric motor just an assistance in terms of locomotion. These engines use a large load/speed spectrum during normal operation in the running cars. On the contrary, newer engines developed as range extenders for electric vehicles are developed to work at a more limited range of load and speed, sometimes only at one or two conditions. $[12,13]$. These engines are much more efficient than the usual "accelerating" engines found in conventional cars, as they always run at specified conditions and are designed only for running at these conditions. In Europe, where the Diesel engine reigns, some of the hybrid cars have Page 2 of 26 
Diesel engines. These cars have a price disadvantage, as Diesel engines are more expensive than spark ignition engines. Hybridizing a SI engine car is also more effective than hybridizing a Diesel engine car, as SI engines have a higher reduction in efficiency when driven at light loads.

Fuel cells are available in various types but vehicles tend to use just PEM (polymer exchange membrane) operating on plain hydrogen. In some cases it is possible to feed natural gas to a reformer, with the produced hydrogen being supplied to the fuel cell. The advantages of fuel cells are their inherent high efficiency, silent operation and the sole production of steam as a byproduct. On the down side, they are extremely expensive and they are easily contaminated, requiring an expensive rebuilt.

\section{INFORMATION STRUCTURE}

A database was built using MS Access structure and Visual Basic programming. This data base can store data related to EVs and their powertrain systems/components such as energy storage systems, motors, controllers, IC engines (in the case of hybrid vehicles), fuel cells, solar PV panels (Figure 1).

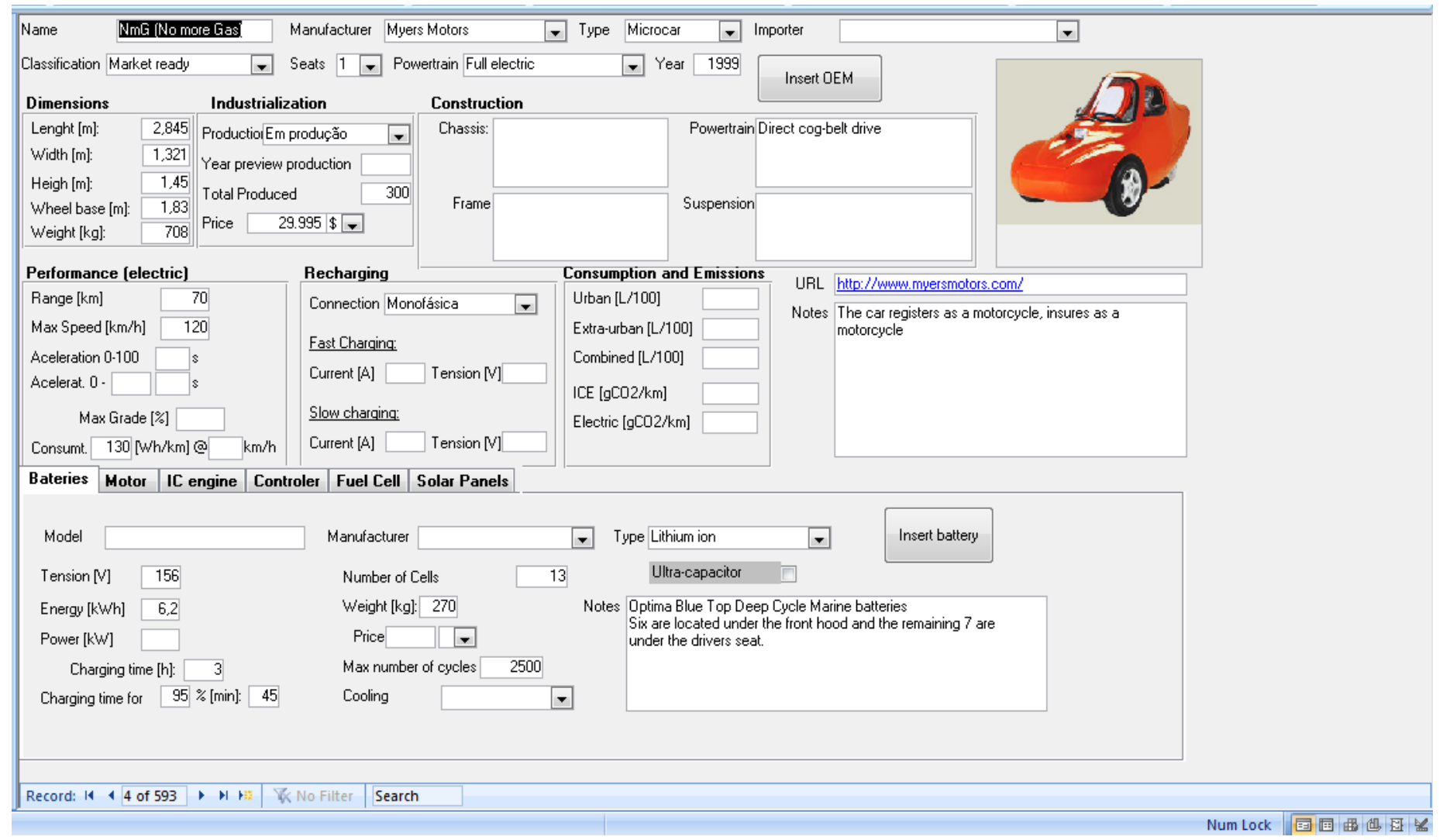

Figure 1 -Electric vehicle model main form in the database.

Electric Vehicle models were categorized using several criteria, the vehicle type, the vehicle powertrain and the vehicle status.

From the first classification criteria vehicles were divided into the following types:

1 Conventional design (Sedan, MPV, SUV, Pick-up)

Page 3 of 26 
3 Microcar / Tricycle

$4 \quad$ NEV / Quadricycle

$5 \quad$ Van \& Utility

$6 \quad$ Bus

$7 \quad$ Truck

8 Competition, Golf cart, ATV, etc

It is worth noting that the difference between an NEV and a personal and microcar is not the size but the vehicle performance, once a NEV has its top speed limited by regulations, while a microcar differs from other cars due to its size and its passenger capacity of usually 2 or less. Two-wheel vehicles were not included in this survey.

A second vehicle classification criterion is the powertrain configuration. In the present work the following powertrain types were considered:

$1 \quad$ Full electric

2 Parallel hybrid

$3 \quad$ Parallel hybrid "plug-in"

$4 \quad$ Electric with range extender or series hybrid

$5 \quad$ Electric with fuel cell

6 Electric with turbine generator

Concerning the vehicle development status field, it is intended to classify each vehicle in an industrial/marketing status, allowing the following categories:

Design concept - Vehicles that have been publicly presented and still exist only in drawings or CAD models. No physical prototype exists yet. Vehicles under this status of development may not go further than this.

Concept car (converted) - Vehicles presented to the public but still not tested, being a conversion from previously existing models and in which just the powertrain has been converted into hybrid/electric. Vehicles under this status of development may not go further than this. These converted vehicles may be presented by the original vehicle manufacturer (OEM) or by a 3rd party company which performs the conversion.

Concept car- Vehicles presented to the public but not tested, which are intentionally designed to be hybrid/electric vehicles. Vehicles under this status of development may not go further than this.

Page 4 of 26 
Demonstration car (converted) - Vehicles presented to the public and tested, which are a conversion from previously existing models and in which just the powertrain has been converted into hybrid/electric. Vehicles under this status of development are very often produced on very small series and tested on specially selected regions or markets. These converted vehicles may be presented by the original vehicle manufacturer (OEM) or by a 3rd party company which performs the conversion.

Demonstration car-Vehicles presented to the public and tested, which are intentionally designed to be hybrid/electric vehicles. Vehicles under this status of development are very often produced in very small series and tested on specially selected regions or markets.

Competition - Single unit (or very small series) vehicles designed and built for competition purposes or for record performance.

Market ready (converted) - Vehicles designed and produced by OEMs from an original model with an IC engine powertrain, but now having hybrid or full electric powertrain. These vehicles are already on the market. Some models of these class of vehicles may have been already taken out of production.

Market ready - Vehicles intentionally designed to be hybrid/electric vehicles. These vehicles are already on the market. Some models of these class of vehicles may have been already taken out of production.

The information concerning a total amount of 593 vehicle models was stored and analyzed, although not all specifications/features were available or released for each of these vehicles.

Considering the vehicle type classification presented above, the first four vehicle types include almost all vehicle models present in the database (Figure 2). The most common vehicle types being released with an electric or hybrid powertrain are Sedans and SUVs. The following is the NEV group. Microcars (including tricycles) and sport vehicles are also used very often. Frequently sport vehicles are also built to prove the effectiveness of the electric powertrain. From all these sport vehicles a significant amount of them are concept cars, as it will be seen below.

Page 5 of 26 


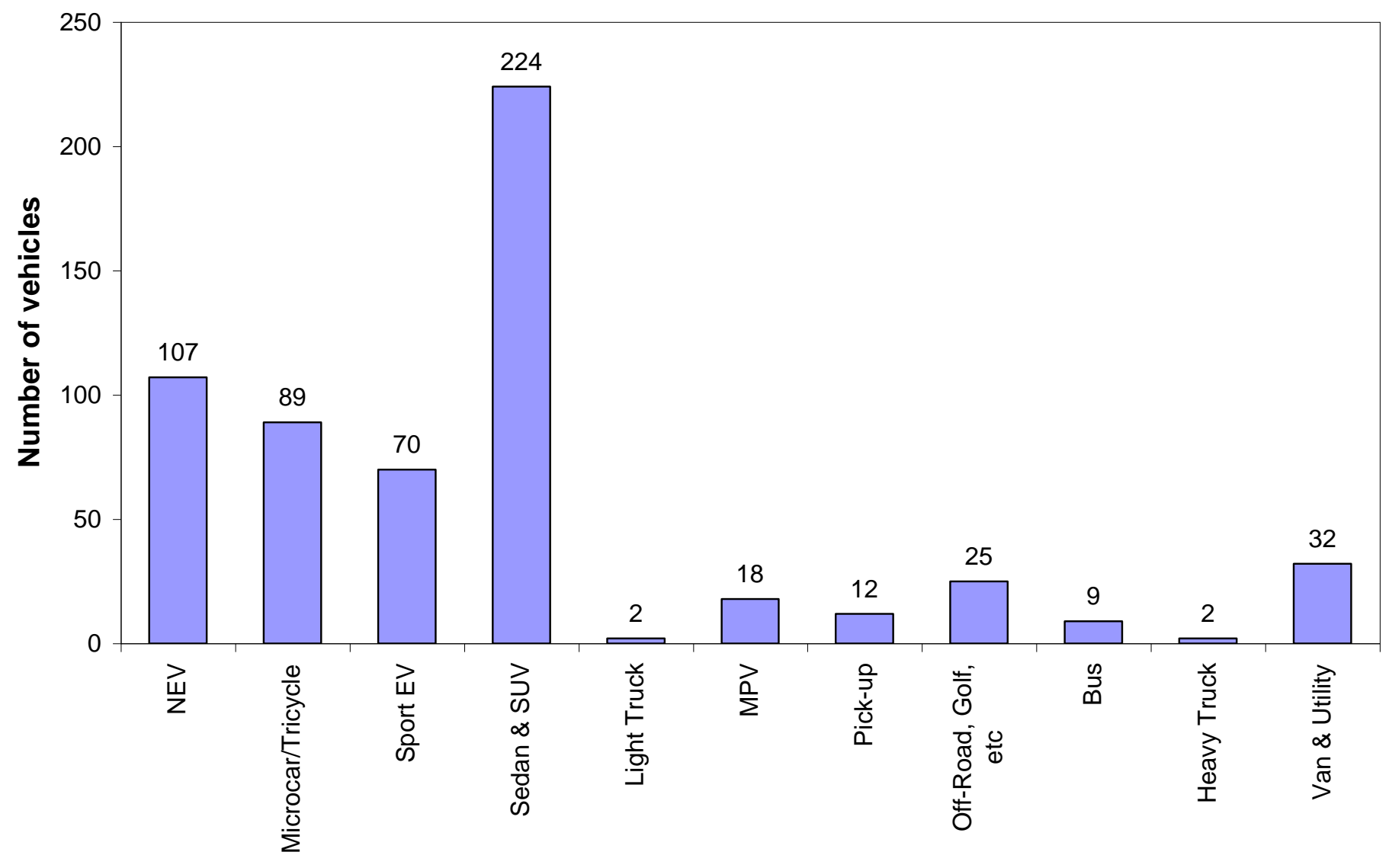

Figure 2 - Number of vehicle models surveyed by vehicle type.

On Table 1 all the vehicle models from the database are divided into to the several possible powertrain configurations, from the full electric to hybrids and electric with on-vehicle power generation devices.

Table 1 - Number of vehicle models by powertrain configuration.

\begin{tabular}{|l|l|}
\hline Powertrain type & $\begin{array}{l}\text { Number of } \\
\text { vehicles }\end{array}$ \\
\hline Full electric & 381 \\
\hline Parallel hybrid & 92 \\
\hline Electric with fuel cell & 52 \\
\hline Electric with range extender ICE & 30 \\
\hline Plug-in hybrid & 18 \\
\hline Electric with turbine & 1 \\
\hline
\end{tabular}

Page 6 of 26 
Nearly $66 \%$ of all surveyed vehicle models were full electric. These exist since over a hundred years. Hybrid vehicles and electric vehicles with on-board power generation (either ICE range extender or hydrogen fuel cells) are more recent and their technology is still under development. That is why only a reduced number of vehicles has been released.

The development status of the released models is also a good information source to understand how this technology stands in terms of maturity. The total amount of vehicle models on this survey and their status of development is shown in figure 3.

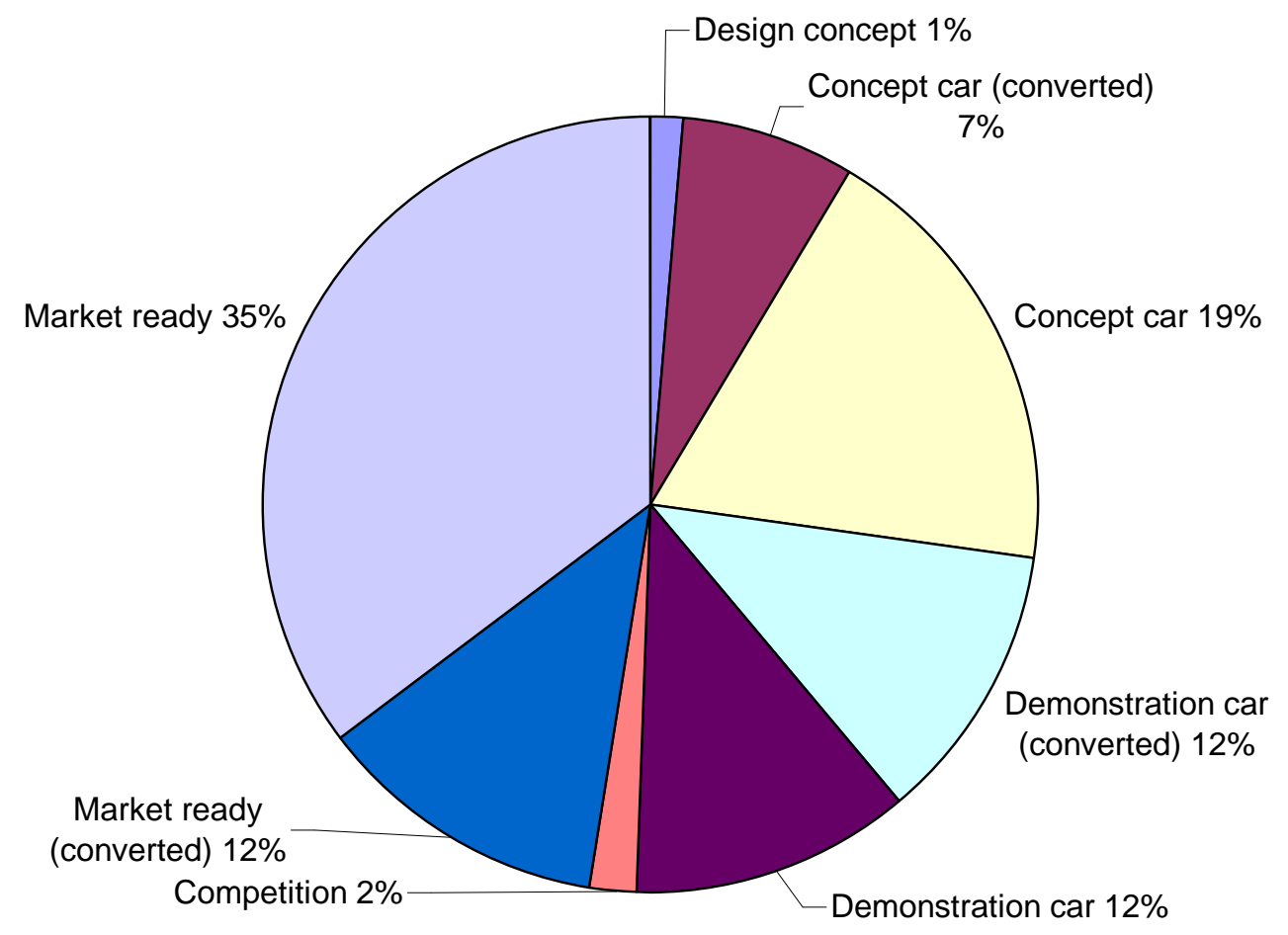

Figure 3 - Vehicle models and their status of development.

As it can be seen from figure 3 , nearly $50 \%$ of all vehicle models have already hit the market. This fact shows that the technology involved on this type of vehicles is still under hard development. Another fact that also corroborates this is the amount of vehicles which are converted from existing conventional powertrain platforms. Nearly $31 \%$ of all vehicles surveyed were built using existing platforms, reducing costs and development time for OEMs.

It is also important to note that from the vehicle models that have been already released to the market, and from those labeled as market ready, $45 \%$ are NEV, $21 \%$ are Sedan or SUV and $14 \%$ are microcars. This reveals the great amount of NEV models on the market and the early stage of development of the major OEMs in terms of releasing full electric vehicles. From another point of view, of the converted market-ready vehicles $46 \%$ of them are sedans and SUVs and 19\% of them are commercial vans and utility vehicles. Again, from these figures it is possible to understand the market strategy followed by OEMs in terms of electric mobility. The main focus is

Page 7 of 26 
put on the development of powertrains using previously developed platforms, leaving the development of completely new designed vehicles for a second stage.

Analyzing the vehicle models from a manufacturing country point of view, it can be seen (Figure 4) that the USA is the leader, with the highest number of vehicles released to date, followed by Japan and China. Only after these three come some European countries. However, if all European Union countries are summed, EU has a higher number of new model vehicles than Japan and China, becoming the second world economy with higher number of new released electric/hybrid vehicles.

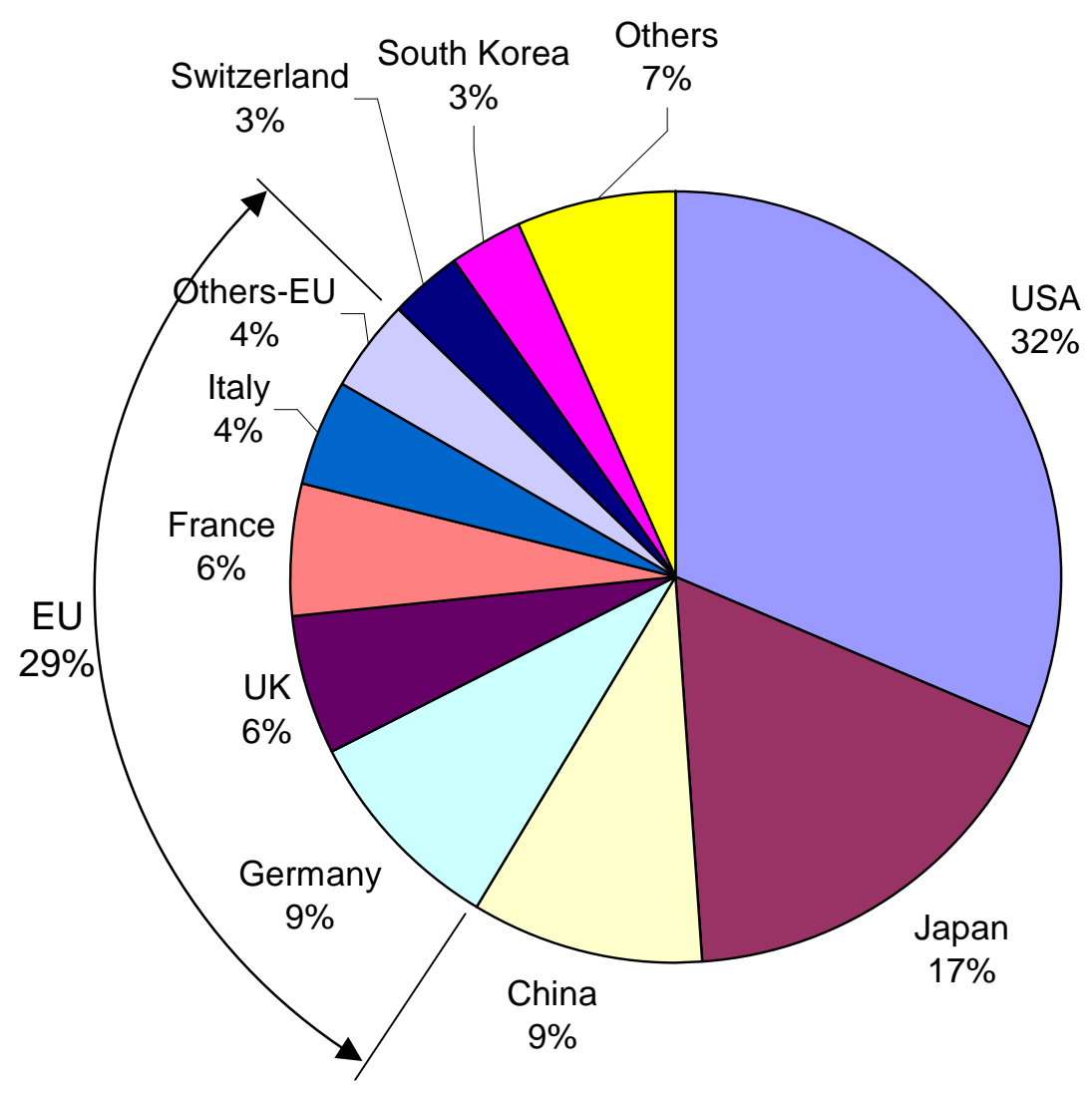

Figure 4 - Percent of new model vehicles per manufacturing country.

Looking with more detail to the hybrid and electric vehicle manufacturing, some other results may be found. In terms of NEVs, for example, and considering that some USA labels have their production in China, $78 \%$ of the models come from these two countries, corresponding 43 to USA and 35 to China. If just hybrid vehicles are considered, then a different composition exists. Japan is the country with more hybrid and plug-in hybrid model vehicles released (42\%), while USA comes in second place with $24 \%$ and Germany with $17 \%$.

The distribution of new model vehicles which hit the market is presented on figure 5 .

Page 8 of 26 


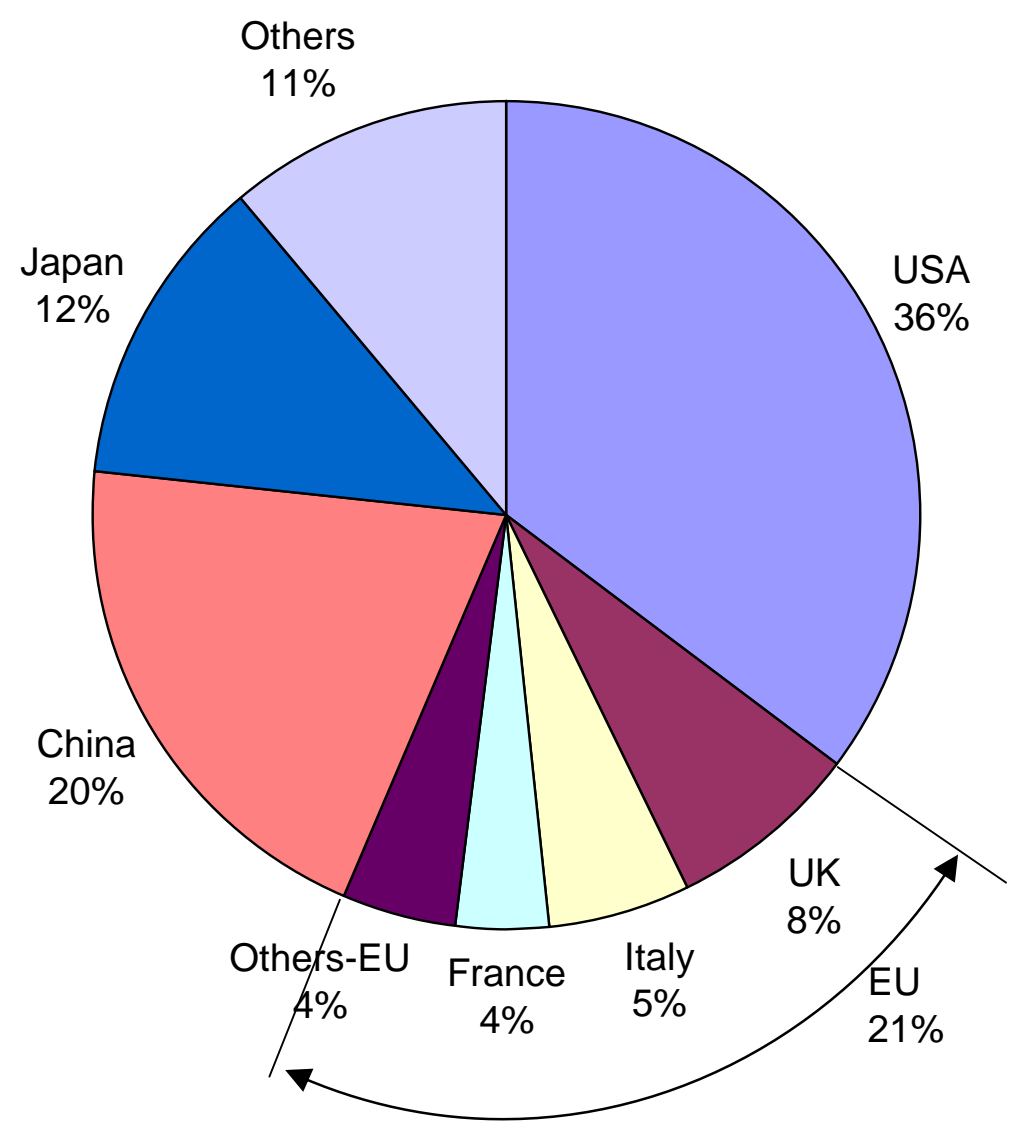

Figure 5 - Distribution of new model vehicles released to the market.

On Figure 5 it can be seen that the role of USA is quite the same but EU comes to the second place in terms of new vehicles released to the market. The role of China is more relevant on this analysis, being at the same level as the total EU countries. This means that China is mainly a manufacturer, once the number of released models is higher than Japan. Comparing the number of models that reached the market to the total number of models released, China displays the best ratio, $89 \%$, followed by UK and Italy with $62 \%$ and USA with $53 \%$. These figures represent the amount spent on R\&D for each country and the complexity of the technology used. In fact, vehicles from China are mostly full electric and from these most are NEVs. These vehicles have a very simple structure and powertrain using lead-acid batteries and DC motors.

\section{VEHICLE TYPES}

\section{NEV}

Neighborhood electric vehicles (NEVs) are the most popular electric vehicles on the market. From a total 107 models analyzed $89 \%$ are on production now, with $7 \%$ without any information on the market situation.

NEVs have their top speed limited as well as their curb weight. The configuration must be a four-wheel vehicle, excluding from this category tricycles. In terms of passengers capacity, NEVs have a distribution such as the one presented on Figure 6. As it can be seen $55 \%$ of all these vehicles have two seating places while other $26 \%$ have four seat capacity. This kind of vehicles are mostly used as golf cars and city cars where maneuverability and space are much more important issues than speed.

Page 9 of 26 


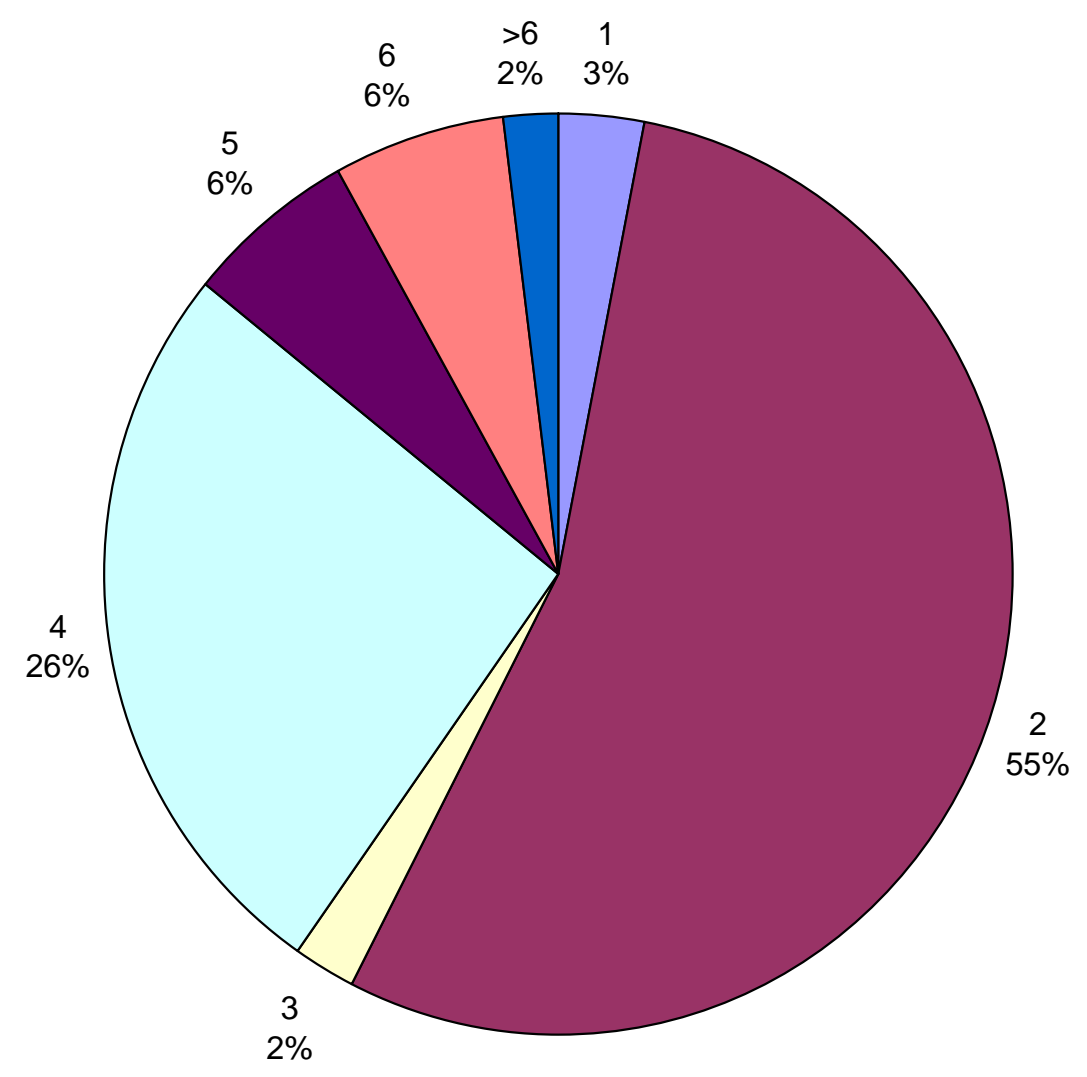

Figure 6 - Number of seating places on NEVs.

On this type of vehicles the most used motor is the DC type (used on 67\% of the surveyed models), with average power around $5.5 \mathrm{~kW}$ and an average peak power of $13 \mathrm{~kW}$. The AC motors are used with less frequency with an average power of $8.4 \mathrm{~kW}$. These motors are used in vehicles which have an average curb weight of $742 \mathrm{~kg}$.

Concerning batteries, NEVs use mostly lead acid batteries (90\%) followed by Li-ion batteries. Unfortunately from the information gathered on these type of vehicles, there is none concerning battery capacity or voltage. The battery packs from NEVs provide an average range of $90 \mathrm{~km}$.

\section{MICROCAR / TRICYCLE}

These vehicles are a kind of upgraded NEVs, since they have a size or capacity of a conventional NEV, but display a higher performance namely concerning their top speed, which is not limited. Such vehicles may assume configurations very different from what is the "norm" on the automotive industry design, such as only three wheels (tricycles), in-line sitting (tandem), just one passenger (the driver), etc. In fact from all personal cars surveyed, near 53\% are already in the market and have original design plus $17 \%$ are in a prototype phase heading for the market. Modified vehicles using existing platforms represent just 5\% of all released models.

In some countries legislation includes tricycles on the motorcycle class, having thus some tax benefits in relation to four wheeled vehicles. The conception of microcars as tricycles has that benefit and that is the reason for its inclusion under this class of vehicles on this survey. 
Microcars and tricycles are almost always commuter vehicles, which are designed to accomplish some high efficiency requirements such as low space/volume occupation, reduced number of places (once on most of daily travels made are on a vehicle, either in US or Europe, the driver is the only passenger), reduced energy consumption. From the vehicles surveyed, the area occupied, on average for this type of vehicles, is 4.4 square meters, while on the conventional sedan vehicles this value goes to 7.4 square meters. This same tendency exists with the number of sitting places on board, where the great majority of the models has 2 or less sitting places. The full electric powertrain is the most widely used (on $92 \%$ of the models released), and the rest, which are just 6 models, have hybrid or range extended powertrains.

As for the top speed obtained with this type of vehicles, it can go as high as $240 \mathrm{~km} / \mathrm{h}$ on the Tango T600 from Commuter Cars, already on the market. In terms of range, the capability offered by batteries can go up to $450 \mathrm{~km}$ on the two Obvio models from Brazil the 828E and the 012E. However no specifications are presented on this vehicle battery except that is of Li-ion technology and a capacity of $39 \mathrm{kWh}$. In fact on this class of vehicles these two models are those which have a higher battery capacity. Batteries are, on a great majority, of the Li-ion type. But their capacity is on average of $11 \mathrm{kWh}$ for the Li-ion type batteries and $8 \mathrm{kWh}$ for the leadacid type.

On this type of vehicles AC motors, either induction or permanent magnet synchronous, are the most widely used. Their power is on average $8.5 \mathrm{~kW}$ continuous and the average peak power is approximately $23 \mathrm{~kW}$. DC motors were identified on just $17 \%$ of the vehicles of this type, with power very similar to the power of the AC motors used.

\section{SPORT EV}

70 vehicle models have been included on the type of sport vehicles. The criteria were the performance as well as the design, usually two seat vehicles. A significant part of these vehicles are concept cars or prototypes. Some are already in the market, however their price is significantly higher than the average car. The average price of a sport electric car is around 116,000\$.

Their performance can be evaluated based on the top speed and vehicle acceleration. The top speed can go up to $330 \mathrm{~km} / \mathrm{h}$ and the acceleration from 0 to $100 \mathrm{~km} / \mathrm{h}$ (or approximately $60 \mathrm{mph}$ ) can reach $2.5 \mathrm{~s}$. All these best performance marks belong to the Shelby Ultimate Aero EV.

In terms of powertrains, two thirds of all sport model vehicles are full electric using one, two or even 4 motors, one for each wheel. These can be either motor-in-wheel or directly linked to the wheel via a transmission axle. Almost all motors identified are AC type. Just one vehicle was identified using DC motors, the Advanced Mechanical Products conversion of the Saturn Sky, which uses two brushless DC motors, one driving each of the two rear wheels. Although the information released about the motors of sport vehicles is too little, the power of the complete powertrain of full electric vehicles goes from $122 \mathrm{~kW}$ continuous to $258 \mathrm{~kW}$ of peak power on average. Looking at the motors individually, their average power goes to $105 \mathrm{~kW}$ and $211 \mathrm{~kW}$ respectively.

On sport vehicles the main energy storage medium is the Li-ion batteries, with an average capacity of $26 \mathrm{kWh}$. Several other types of batteries are used but only one or two models were identified for each of these other types.

\section{SEDAN \& SUV \& MPV \& PICK-UP}

On this vehicle group a total of 254 models are included. In terms of powertrain they are divided as presented on Table 2.

Page 11 of 26 
Table 2 - Number of vehicle models by powertrain configuration.

\begin{tabular}{|l|l|}
\hline Powertrain type & Number of vehicles \\
\hline Full electric & 108 \\
\hline Paralel hybrid & 72 \\
\hline Electric with fuel cell & 40 \\
\hline Electric with range extender ICE & 17 \\
\hline Plug-in hybrid & 12 \\
\hline Electric with turbine & 1 \\
\hline
\end{tabular}

As can be seen, there is a significant effort of the auto industry on the full electric vehicles and on parallel hybrids. Analyzing these types of vehicles from the models development stand point (Table 3) it can be seen that a significant amount of these type of vehicles are in fact modifications from previously developed platforms but with different powertrains, made by the original manufacturer or other companies specialized on powertrain conversions. There is still also a significant amount of concept cars meaning that industry is still on an early phase of development of such vehicles, once the amount of vehicles that do not hit the market is significant.

Table 3 - Number of vehicle models by development status.

\begin{tabular}{|l|l|}
\hline Development status & Vehicles \\
\hline Concept car & 54 \\
\hline Demonstration car (converted) & 47 \\
\hline Market ready & 46 \\
\hline Market ready (converted) & 42 \\
\hline Demonstration car & 33 \\
\hline Concept car (converted) & 29 \\
\hline Design concept & 1 \\
\hline
\end{tabular}

In terms of batteries on this type of vehicles, Li-ion battery type is the most used, on $45 \%$ of the models surveyed. The second most used battery type is the NiMH type, specially used on hybrid vehicles, where a small energy storage capacity is needed. In the case of the Li-ion batteries the average energy storage capacity is $20 \mathrm{kWh}$, while in the case of the NiMH batteries this value drops to an average $9.2 \mathrm{kWh}$.

Page 12 of 26 
AC induction motors are the most powerfull and those with the highest torque among all motor types used in this type of vehicles. Continuous power averages $62 \mathrm{~kW}$ while the peak power is $103 \mathrm{~kW}$. For this motors the average torque is $349 \mathrm{Nm}$. The motor most widely used is the permanent magnet synchronous AC motor, with less power than the previous ones $(32 \mathrm{~kW})$ and torque of $212 \mathrm{Nm}$. DC motors are also used however with much lower frequency and with much lower power. The average power of these motors is $19 \mathrm{~kW}$ with torque averaging $178 \mathrm{Nm}$.

\section{POWERTRAIN}

\section{FULL ELECTRIC VEHICLES}

Full electric vehicles have their range limited by battery capacity. The R\&D efforts on this technology are nowadays under a great pressure aiming at the increase of power density and of battery life cycle. From the vehicles analyzed it can be concluded that since 1989 the maximum range increased five times from $80 \mathrm{~km}$ to $400 \mathrm{~km}$ in 2009 announced for the BYD E6. However, the great majority of new released models have their range within the lower values, as presented on Figure 7. The average range of the vehicles released each year shows a clear tendency for an increase as a result of the development of the batteries industry.

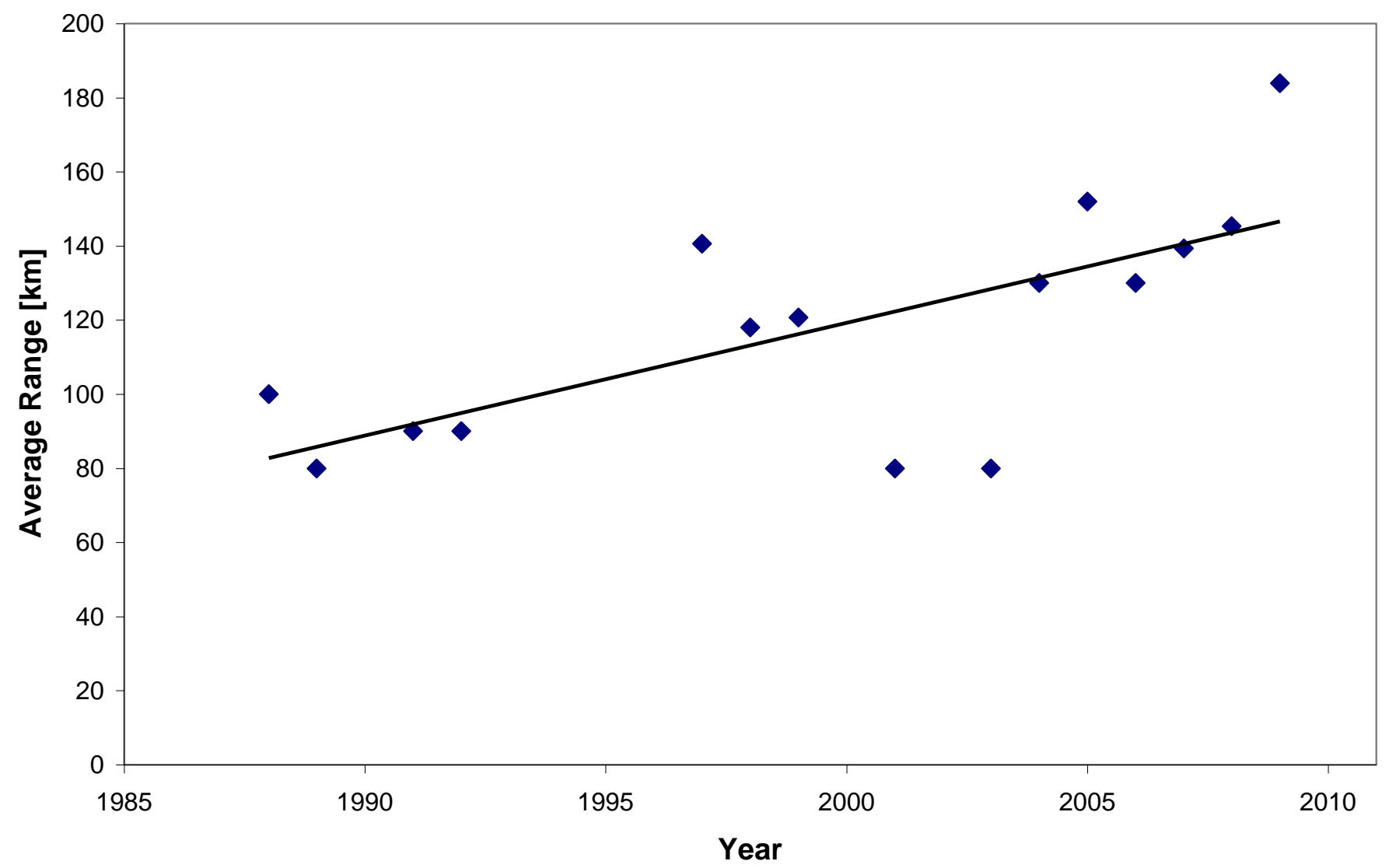

Figure 7 - Average range of full electric vehicles.

Concerning the electric motors used in full electric vehicles, $59 \%$ of new models opted for the use of AC motors and from these the most used type was the AC induction motor with an average continuous power of $40 \mathrm{~kW}$. Electric vehicles using DC motors mostly use those of separate excitation, with an average power of 8.5 Page 13 of 26 
$\mathrm{kW}$. Clearly these are typically used in NEVs, while the AC motors are preferred in vehicles with higher power demand. In fact, the peak power of DC motors averages at $29 \mathrm{~kW}$, while for AC motors the average peak power goes to $84 \mathrm{~kW}$.

On this type of powertrains, it is possible to use the motor-in-wheel, or motor-in-hub technology and the motors used for this type of applications are usually different from the previous, since their torque requirement is higher. In fact, the motors used in this application have an average torque of $700 \mathrm{Nm}$ in the case of the AC induction motors and $772 \mathrm{Nm}$ in the case of the AC permanent magnet motors.

Considering the batteries used in full electric vehicles, from a total 227 new models, $45 \%$ use Li-ion batteries and $27 \%$ use lead-acid. Other types of batteries represent less than $10 \%$ of new models. The lead-acid battery vehicles display the smallest range, with a fleet average of $96 \mathrm{~km}$, while the Li-ion battery vehicles have an average range that goes up to $227 \mathrm{~km}$. In terms of battery pack voltage, again the lead-acid vehicles have much lower voltages $(79 \mathrm{~V})$ than $\mathrm{Li}$-ion with an average fleet voltage of $208 \mathrm{~V}$.

The significant increase of the use of Li-ion batteries since 2007 must be referred. The release rate of new models with each type of battery has been around 3 per year. Except for the Li-ion battery type, which had 10 new vehicles released in 2008 and 9 in 2009, showing the increased interest and development put on this type of battery.

\section{PARALLEL HYBRID VEHICLES}

Parallel hybrid vehicles include vehicles with powertrains that use both electric power and ICE power. Also included in this category are parallel hybrid vehicles which can be plugged in for battery recharge, also known as Plug-in Hybrid Electric Vehicles (PHEV). This type of powertrain can use both electric-only mode, ICEonly mode or both power sources simultaneously. Although widely known as parallel hybrids the positioning of the electric motor in relation to the ICE can assume several possible assemblies. In some cases, the electric motor is assembled in parallel with the ICE and both are linked with a planetary geartrain to have only one output shaft normally linked to the gear box. This is the case of the Toyota Prius [14]. Another positioning is the one presented by Honda with their Integrated Motor Assist (IMA) system [15] where the motor is placed in the position of the flywheel in conventional ICE engines. This motor is used as motor and generator. In the case of Peugeot 3008 Hybrid4 system, a Diesel engine is used to power the front wheels, while an electric motor powers the rear wheels. Ford presented its concept Reflex which has a diesel hybrid powertrain on the front axle and an additional electric motor to power the rear axle.

OEMs are releasing a significant number of vehicle models with this type of powertrain configuration. From Figure 8 it can be seen that from 2003 the rate of new models release is increasing until now. 


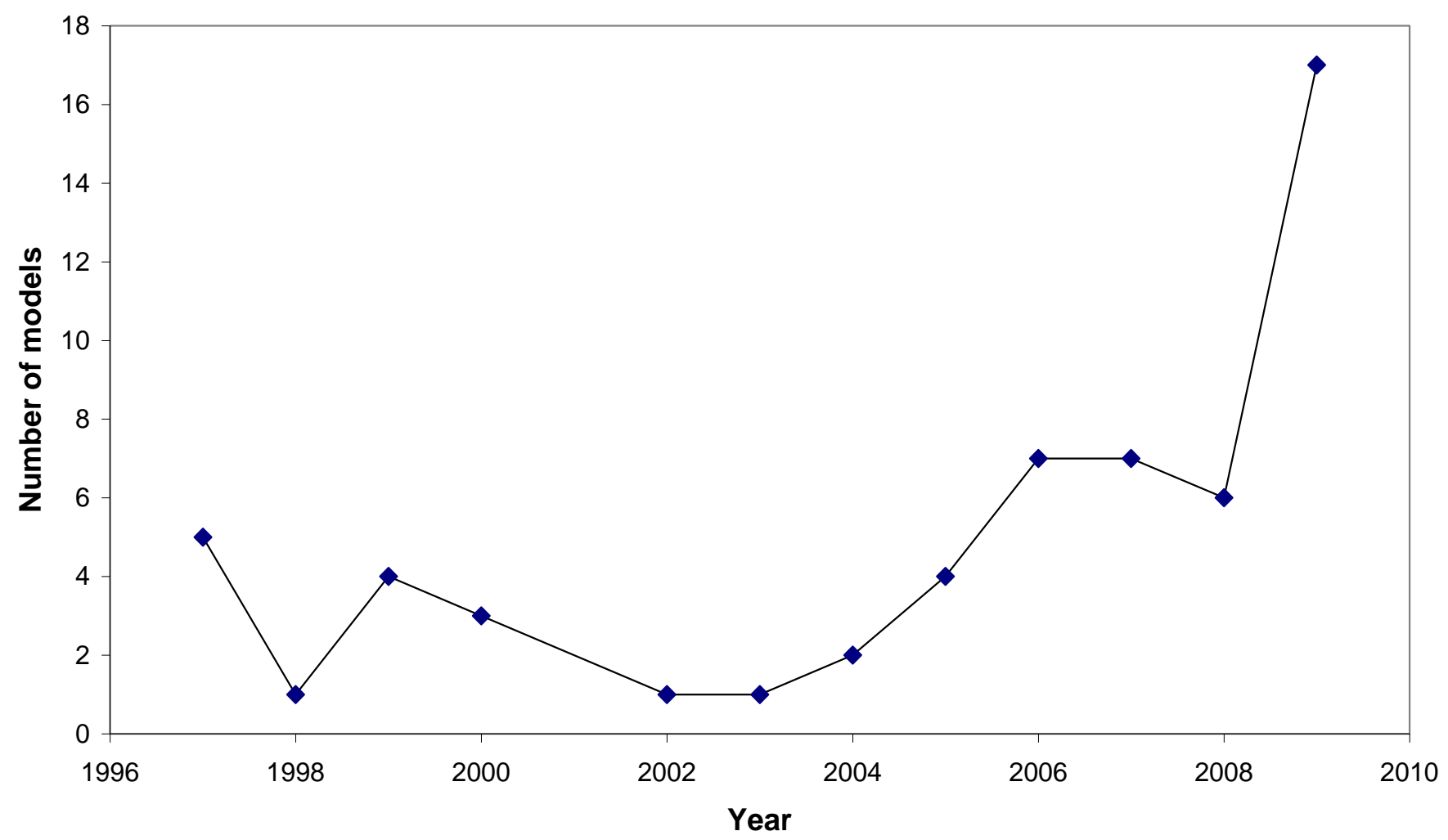

Figure 8 - Rate of parallel hybrid new model vehicles released per year.

The engines used in hybrid vehicles usually are conventional ICE with some improvements in terms of fuel economy such as the adoption of the Atkinson cycle, cylinder deactivation and shutting off of part or all cylinders during speed reduction or braking. Some of these vehicles have curb weights over $2000 \mathrm{~kg}$ and their IC engines have powers over $200 \mathrm{~kW}$. In the case of the GMC hybrids the engine is the 6.0L Vortec V8 VVT, LIVC with Active Fuel Management, with 248 kW (332 hp) power.

Electric motors mostly used in this type of powertrains are AC permanent magnet synchronous. About $50 \%$ of new parallel hybrids use this type of motor with an average power of $30 \mathrm{~kW}$ and a peak average power of 97 $\mathrm{kW}$. Other types of AC motors (induction) are also used but with much less frequency. DC motors are used in $23 \%$ of new models when reduced power level is required, with rated average power of $7.5 \mathrm{~kW}$.

For this type of vehicles, $54 \%$ of new models released have NiMH battery packs and $21 \%$ have Li-ion batteries. The battery cost may be the main factor for the great predominance of the NiMH battery type. For this type of powertrain the required battery energy storage capacity is not high (just enough to perform a few vehicle accelerations), thus the problem of weight and volume of the battery pack is not an issue.

\section{RANGE EXTENDED ELECTRIC VEHICLES}

Extended range electric vehicles are vehicles with a battery pack displaying a capacity which is similar to that of full electric vehicles and motor(s) with a power which is equivalent to that of full electric vehicles. The only difference is that they have an on-board electric generator powered by an internal combustion engine.

Page 15 of 26 
In this type of powertrain the main engine configuration is the naturally aspirated spark ignition engine. The spark ignition engine was used in $64 \%$ of them, followed by the compression ignition present in 3 models (see Table 4). Two vehicles were identified as having a supercharged direct injection spark ignition engine as range extender, the Fisker Karma and a converted vehicle from Raser Technologies which uses a Hummer SUV. And again only one vehicle displayed a supercharged spark ignition engine, the Opel Ampera.

Generally, the IC engine/generator power for range extenders is bellow $70 \mathrm{~kW}$, providing additional vehicle ranges of more than $500 \mathrm{~km}$. The exception is again the Fisker Karma, which has an engine of $198 \mathrm{~kW}$.

Most of the engines used for range extenders use the Atkinson cycle having a longer expansion stroke than the compression, with a significant increase of the engine thermal efficiency and thus fuel consumption reduction.

Table 4 - Engine types used for range extenders.

\begin{tabular}{|l|l|l|}
\hline Engine type & Vehicles & {$[\%]$} \\
\hline CI & 3 & 13.6 \\
\hline CI - turbo & 2 & 9.1 \\
\hline SI & 14 & 63.6 \\
\hline SI - DI & 1 & 4.5 \\
\hline SI - turbo - DI & 2 & 9.1 \\
\hline SI - turbo & 1 & 4.5 \\
\hline
\end{tabular}

In this type of vehicles Li-ion batteries represent almost $76 \%$ of the cases, followed by other types of batteries with much less frequency. In the case of the Li-ion batteries the range provided by the battery pack had an average value of $72 \mathrm{~km}$.

\section{FUEL CELL VEHICLES}

52 fuel cell (FC) powered vehicle models have been surveyed and from these only two are already in the market, the Honda FCX Clarity and the Mercedes-Benz Class B F Cell. The former was released at the end of 2008, while the latter was announced for the beginning of 2010. The number of fuel cell vehicles released annually is presented in Figure 9. As it can be seen, the increase of new model vehicles is significant, showing the interest of almost all OEMs in this technology.

The main cause for the lack of market penetration of this automotive technology is the hydrogen supply infrastructure which is still at its early stages and the extremely high price of the fuel cell stack. To overcome these issues OEMs propose different approaches: For instance, Honda proposes and a domestic natural gas reformer to fuel their Fuel Cell vehicle FCX Clarity [16]. 


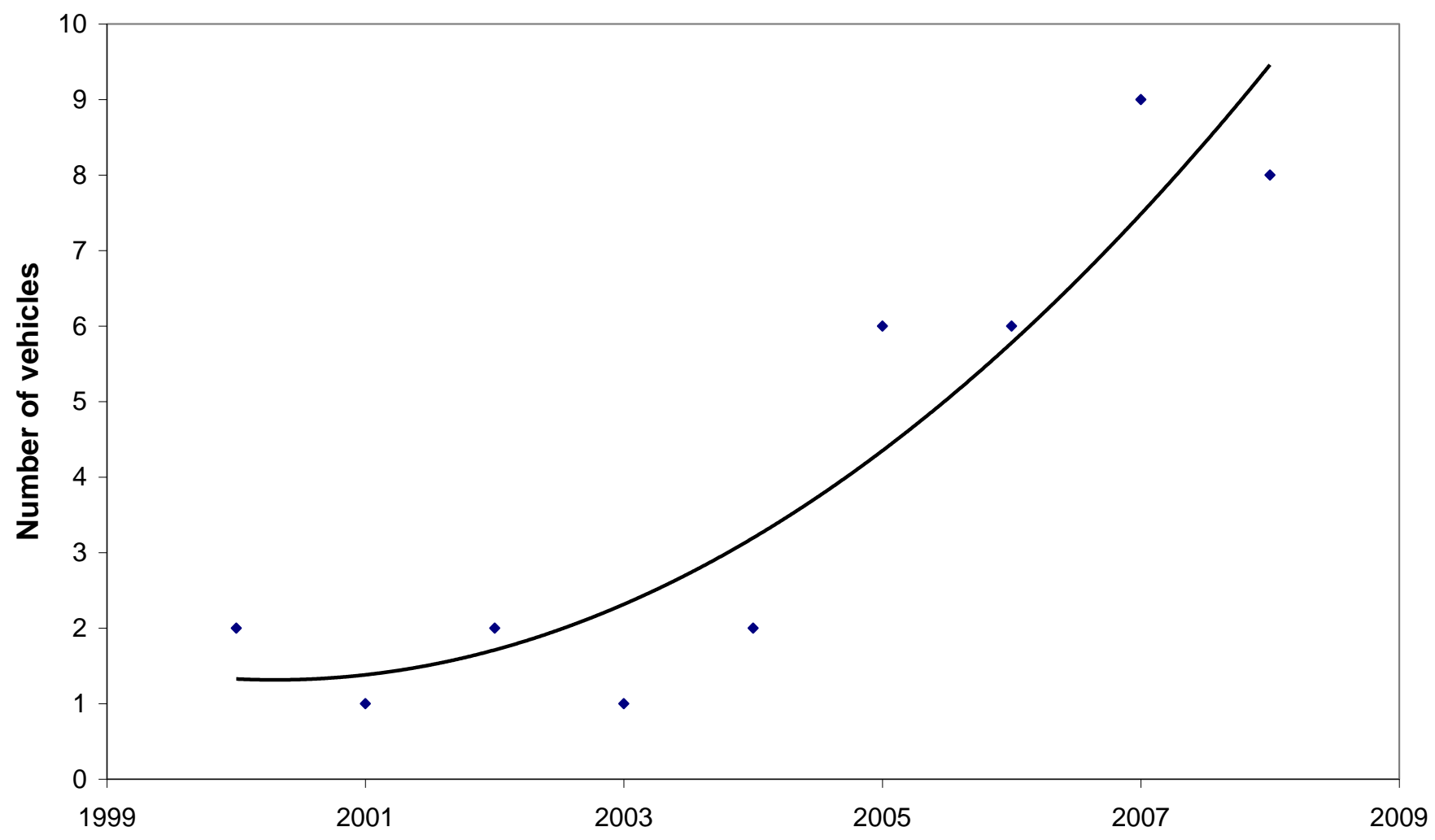

Figure 9 - Rate of fuel cell new model vehicles released per year.

The batteries used in FC vehicles are mainly Li-ion and NiMH. When using Li-ion batteries, the battery pack is able to supply $12.5 \mathrm{kWh}$ in average, while if NiMH type is used, the energy capacity of the battery pack falls to an average $6.2 \mathrm{kWh}$. Fuel cell vehicles display an average range of $92 \mathrm{~km}$ when relying solely in battery power. The fuel cell increases this range usually by 200 to $800 \mathrm{~km}$. The fuel cell starts working when further range is required beyond the capacity of the batteries.

From the data collected only proton exchange membrane (PEM) fuel cells are used in automotive applications. They are fed with hydrogen either reformed on board [17], or stored in tanks on board, using pressures from 350 to 700 bar and with volumes that usually can go from 75 to 150 liters. A relation obviously exists between the fuel cell power and vehicle weight as shown in Figure 10. 


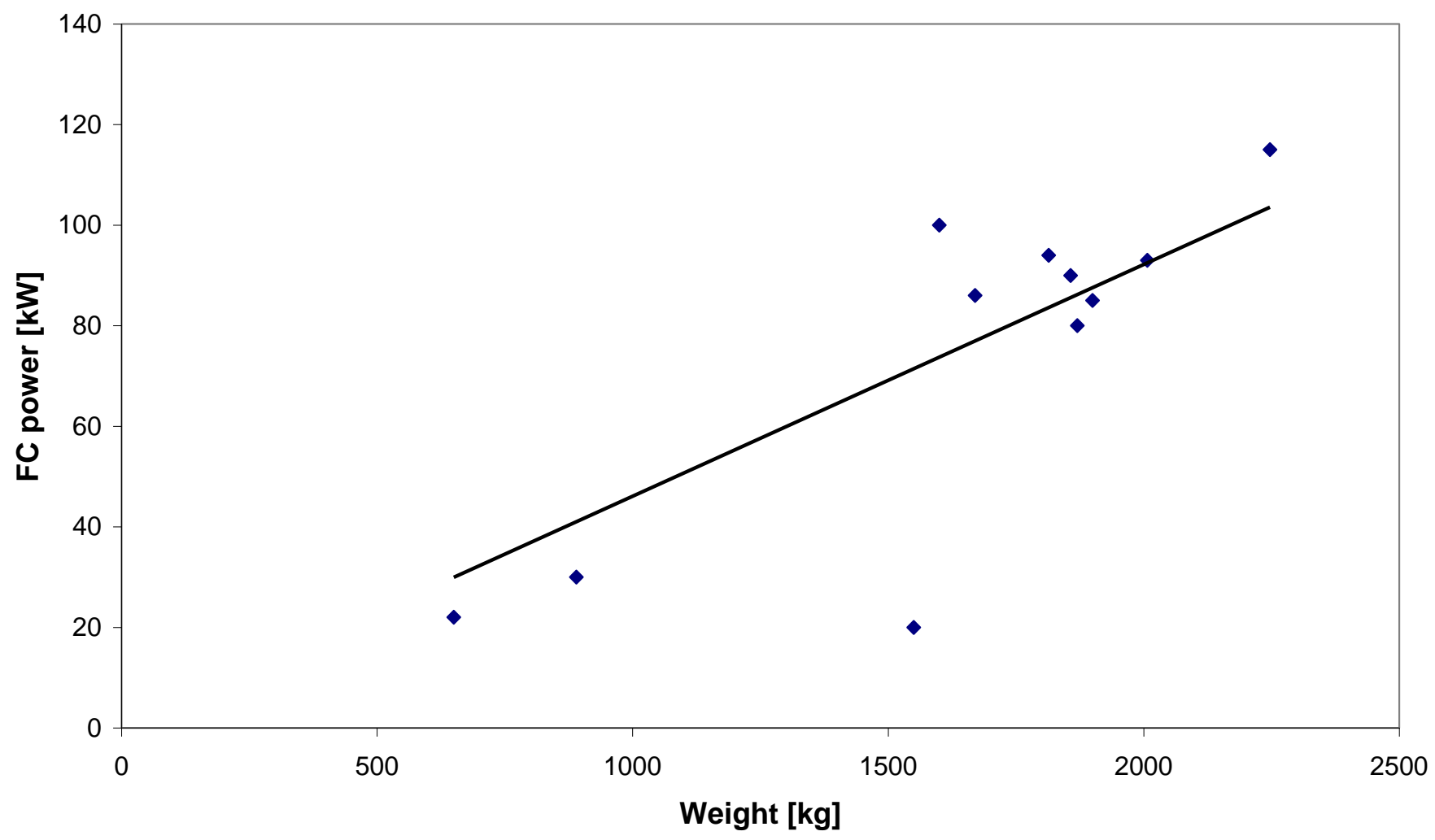

Figure 10 - Relation between the vehicle weight and the fuel cell power.

As it can be seen, fuel cell power has an approximately linear relation with vehicle weight. This relation can be established at $0.05 \mathrm{~kW} / \mathrm{kg}$ of vehicle mass. It is worth noting that a significant number of vehicles with fuel cells have a curb weight higher than $1500 \mathrm{~kg}$. This is justified by the volume needed for the hydrogen storage, which demands a bigger body and thus a heavier vehicle. For this reason it is not expected that a wide variety of commuters with microcar size with a fuel cell powertrain will exist.

Fuel cell vehicles are full electric using mainly AC motors. In fact just one model was found using DC motors, the Pac-Car from Esoro, which is a small competition vehicle. The motors from FC vehicles display an average power of $81 \mathrm{~kW}$. Most often these vehicles deploy a single motor linked with a differential either to the front or rear wheels. When several motors are used, the solution of the motor-in-wheel is preferred over the direct link using a cardan joint.

\section{BATTERIES}

Vehicles with ICE range extenders, fuel cells, and mild and full hybrid parallel powertrains all have battery packs but usually with smaller available range. By gathering the information from all these vehicle types (including full electric vehicles) and by relating the vehicle weight with the corresponding energy consumption it is possible to find a relation between these two variables as shown on Figure 11.

Page 18 of 26 


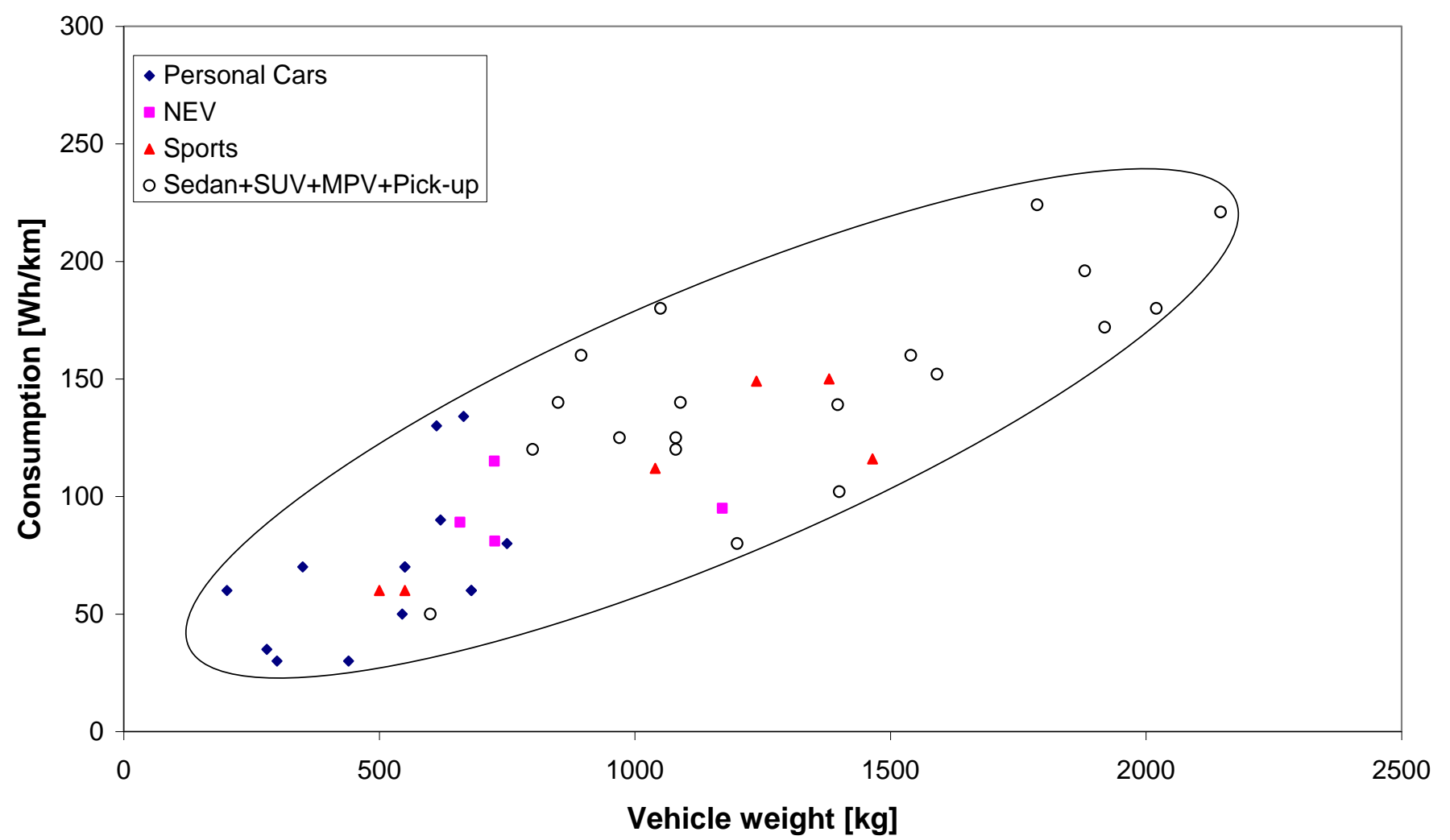

Figure 11 - Energy consumption as a function of vehicle weight.

As it can be seen, a clear relation exists between the vehicle weight and its consumption. This means that a significant effort must be put on vehicle weight reduction so that an improvement on energy saving may be attained. From Figure 11 a relation representing on average $0.1 \mathrm{Wh} / \mathrm{km}$ for each $\mathrm{kg}$ of vehicle mass can be drawn.

Concerning batteries and the vehicle range they provide, a relation between these two variables may be estimated, as presented on Figure 12. Despite the dispersion of the results, it is possible to apprehend a relation of roughly $5.5 \mathrm{~km}$ of range per each $\mathrm{kWh}$ of energy capacity/stored in the battery pack. It can also be seen from Figure 12 that Li-ion battery packs are mainly used for longer vehicle ranges while lead acid, $\mathrm{Ni}-\mathrm{Cd}$ and $\mathrm{Na}-\mathrm{Ni}$ $\mathrm{Cl}$ battery types are used for shorter range vehicles. The main reason for this is clearly the battery pack weight.

Page 19 of 26 


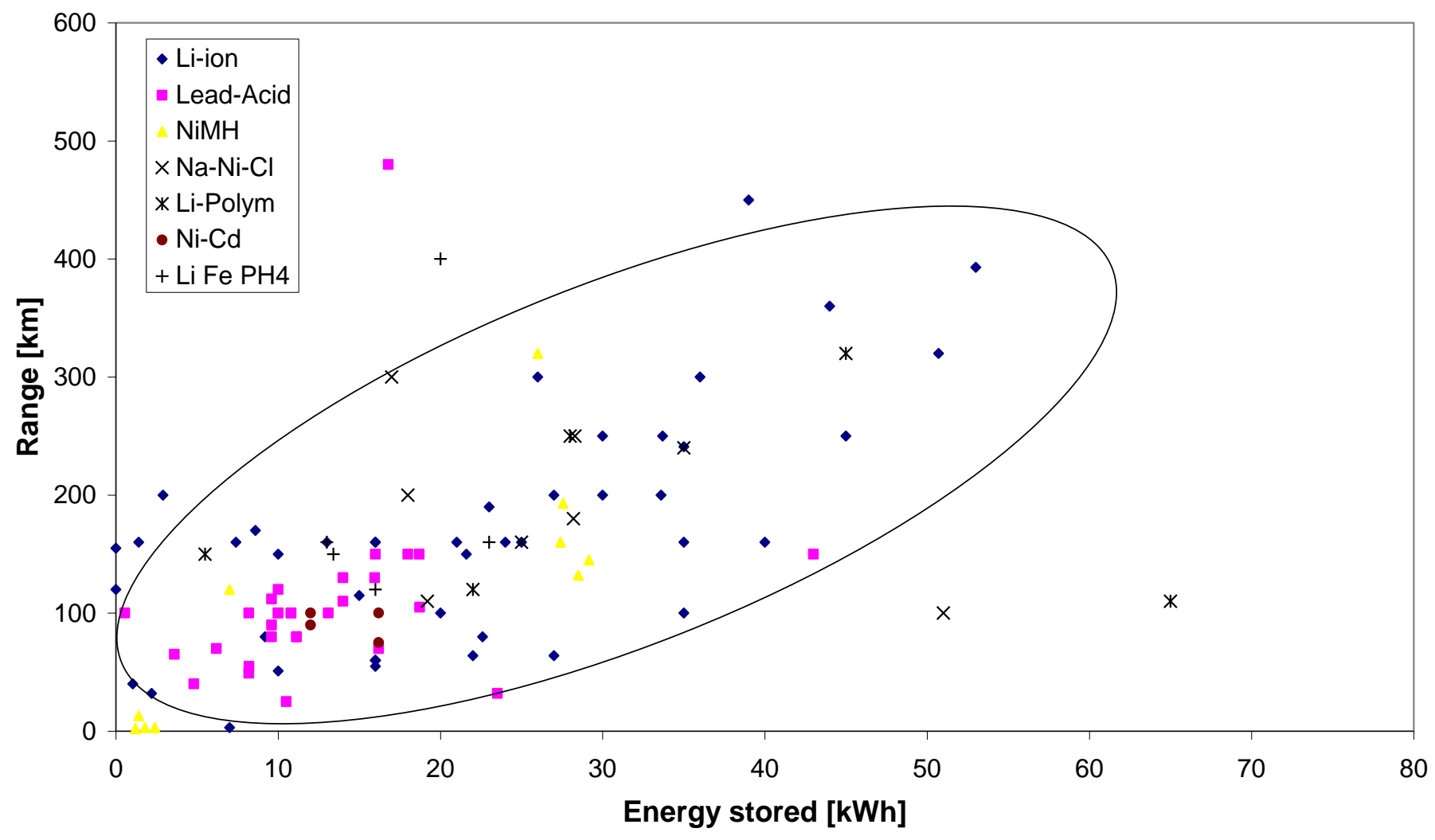

Figure 12 -Vehicle range as a function of battery energy stored and battery type.

The comparison of the battery pack weight with the corresponding energy stored (shown in Figure 13), clearly highlights the potential of the Li-ion battery type. In Figure 13 two zones are shown representing the Li-ion and lead-acid battery packs in terms of relation between weight and energy stored. From the information gathered, Li-ion battery packs have three times more energy density than lead-acid battery packs. The other advantage is the battery life, that in the case of the lead-acid is reported by vehicles manufacturers to be around 500 cycles while for the Li-ion the battery average life is 2700 cycles. All these advantages have put a strong focus on $\mathrm{Li}$ ion battery development, with car manufacturers starting up new industrial projects for mass production of these battery packs [18]. The results concerning the NiMH batteries presented in Figure 13 may be divided into two zones, which are approximately between the Lead-Acid and Li-ion battery packs zones. This means that their energy density is higher than that of Lead-based batteries but lower than Lithium-based ones. A first zone of reduced energy stored corresponds to the mild hybrid vehicles. A second zone exists, with higher energy stored than the lead battery packs.

Some vehicles report the use of ultra-capacitors. These have higher power than any battery pack and simultaneously have reduced energy density, with higher life duration than battery packs. However, no detailed information is released about specifications of the ultra-capacitors used on these vehicles. The use of these technologies will allow for higher rates of regenerative braking energy recovery, due to its higher power.

Page 20 of 26 


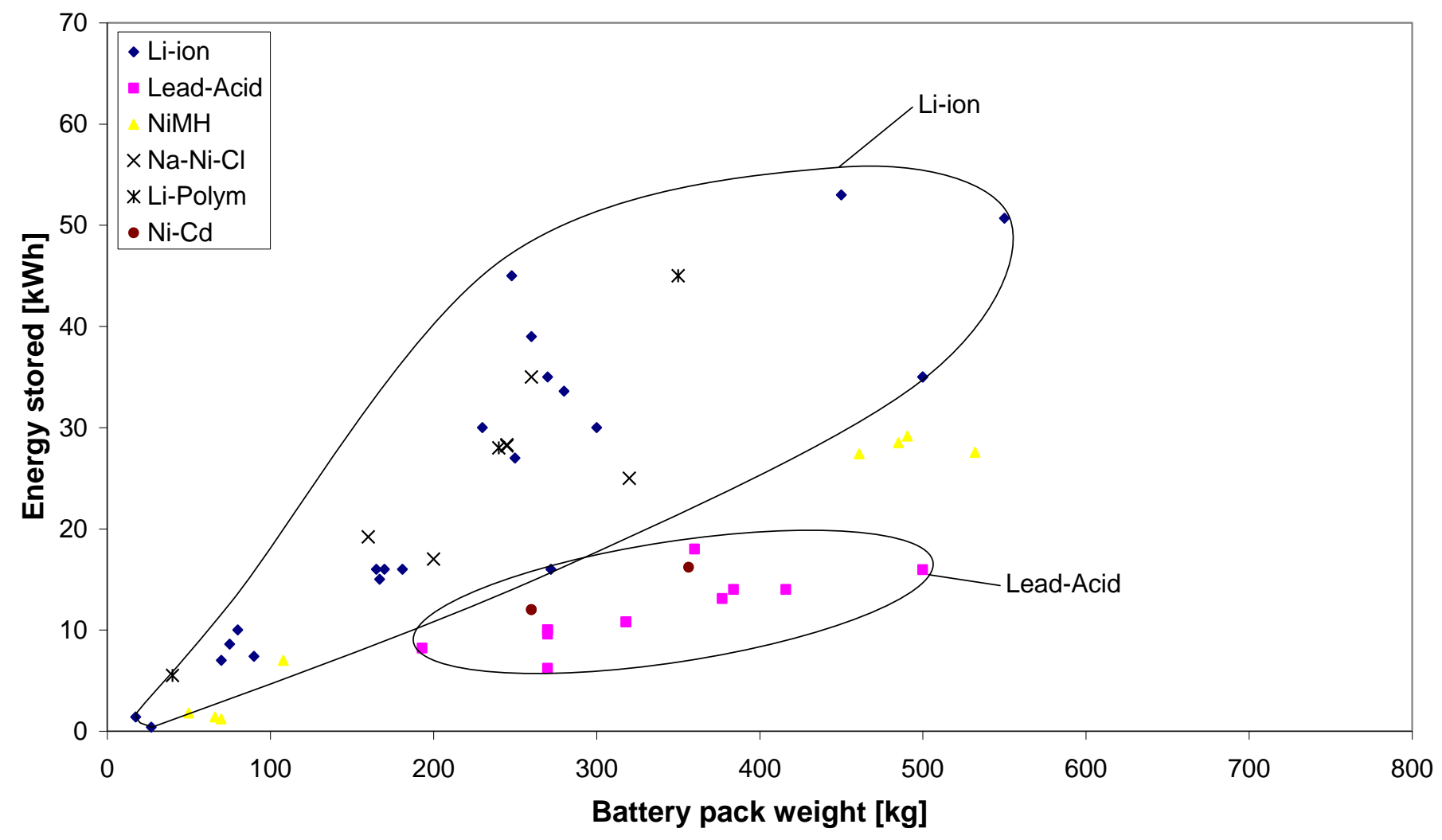

Figure 13 - Energy stored on the battery pack as a function of battery pack weight and battery type.

\section{ELECTRIC MOTORS}

Electric motors are mostly described on vehicle specifications with their peak power. Some times the continuous power is also presented. From these data was possible to compare this two motor characteristics. This comparison is shown on Figure 14. It can be stated that on average the peak power is 1.5 times the continuous power.

Page 21 of 26 


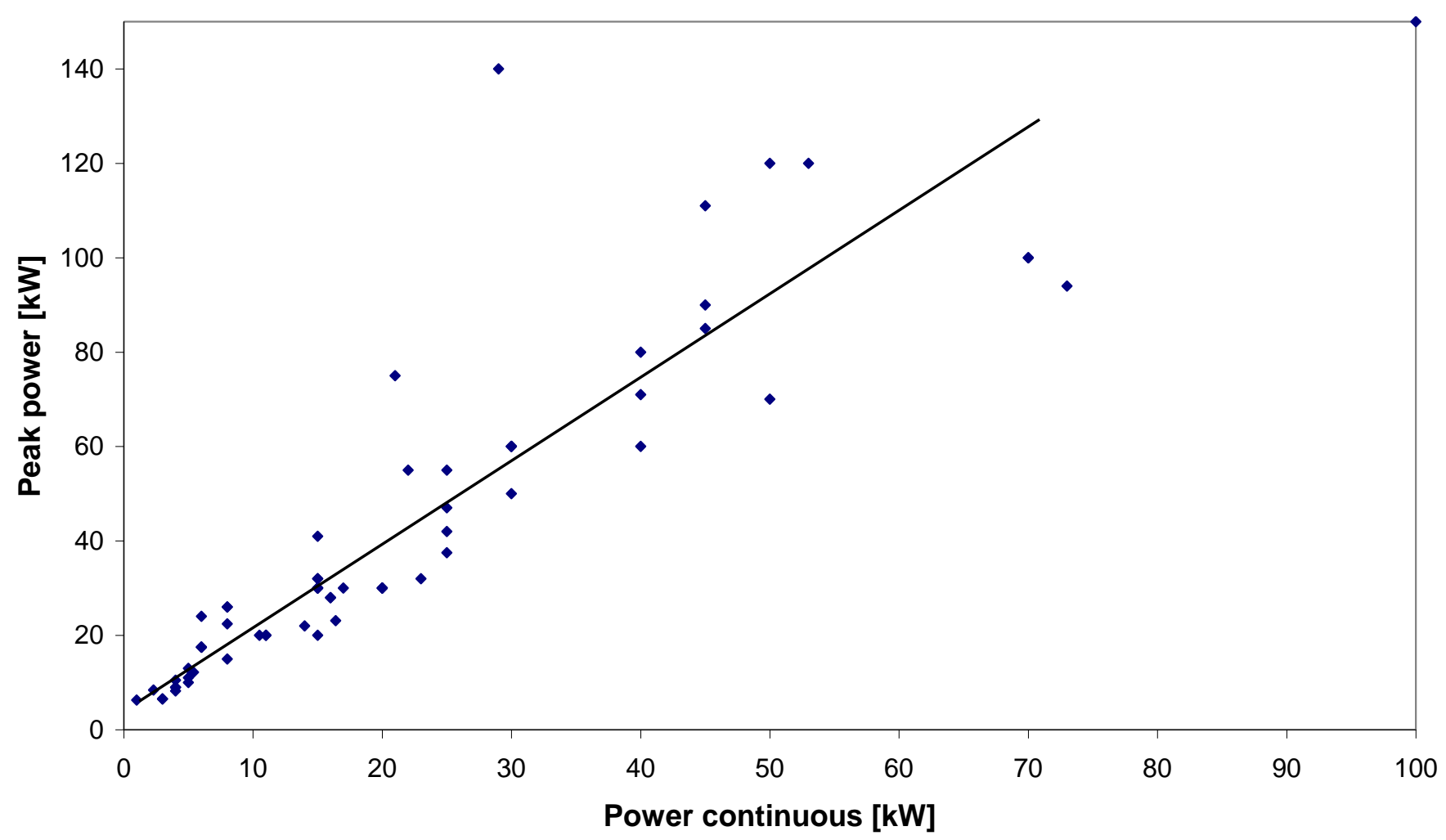

Figure 14 -Relation between the continuous and peak power of vehicle motors.

Peak power on electric motors is available during short working periods from a few seconds until 1 minute, although is not common a so long period of time to work under peak power conditions. Usually this power is used for quick vehicle accelerations. A relation can also be made between these two variables as presented on Figure 15. That relation can be estimated based on the data collected from motors and vehicle acceleration times from 0 to $100 \mathrm{~km} / \mathrm{h}$ under full electric working conditions. The relation between the peak power and the acceleration was preview to be $19 \mathrm{~kW}$ to reduce $1 \mathrm{~s}$ on the 0 to $100 \mathrm{~km} / \mathrm{h}$ time.

Page 22 of 26 


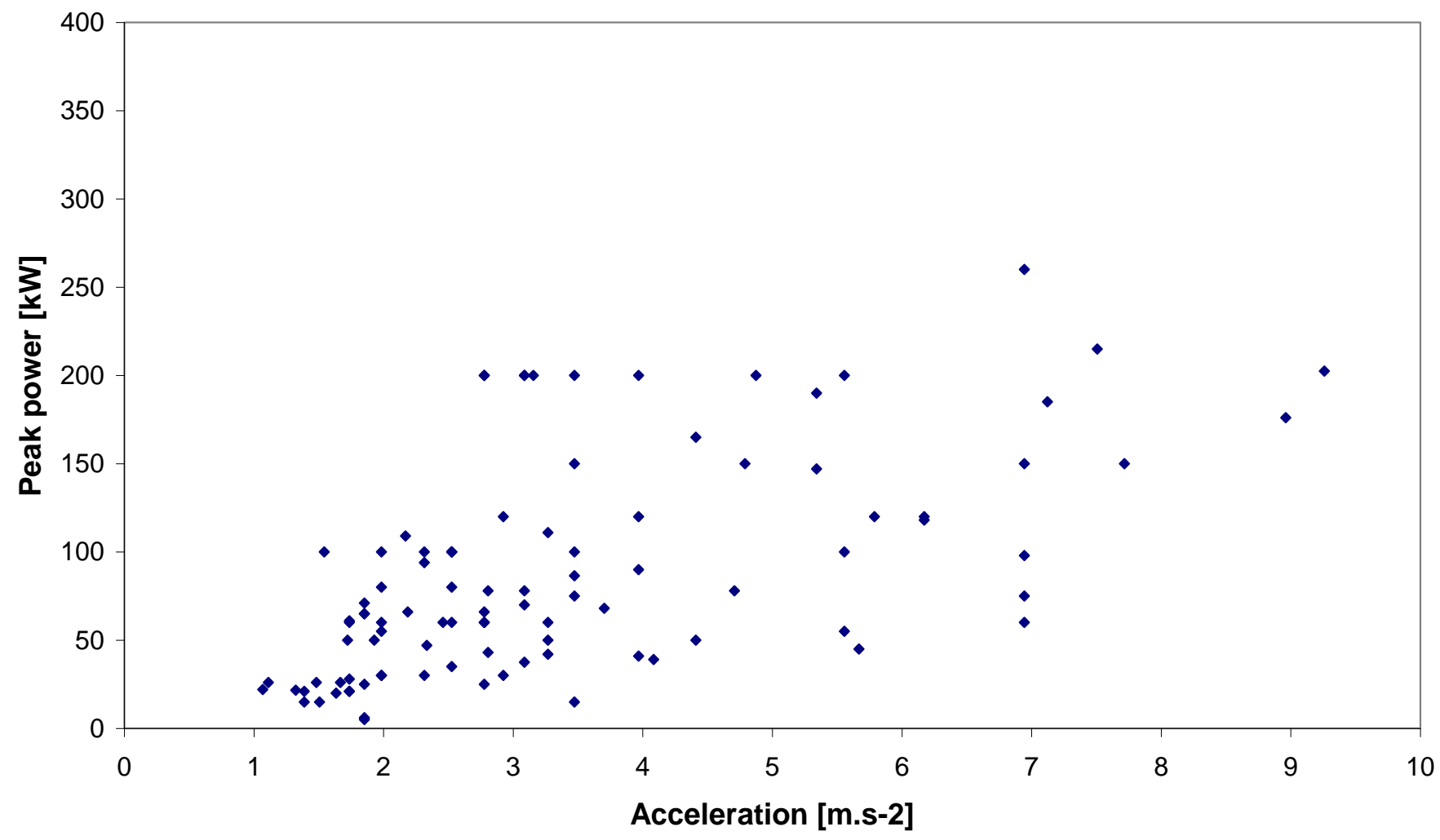

Figure 15 -Relation between the peak power and vehicle acceleration.

The selection and dimensioning of electric motors to electric/hybrid vehicles is also dependent on the vehicle mass as shown on Figure 16. From Figure 16 the relation between these two variables is calculated as $0.025 \mathrm{~kW}$ of motor power per $\mathrm{kg}$ of vehicle mass, bit the data is scattered.

Page 23 of 26 


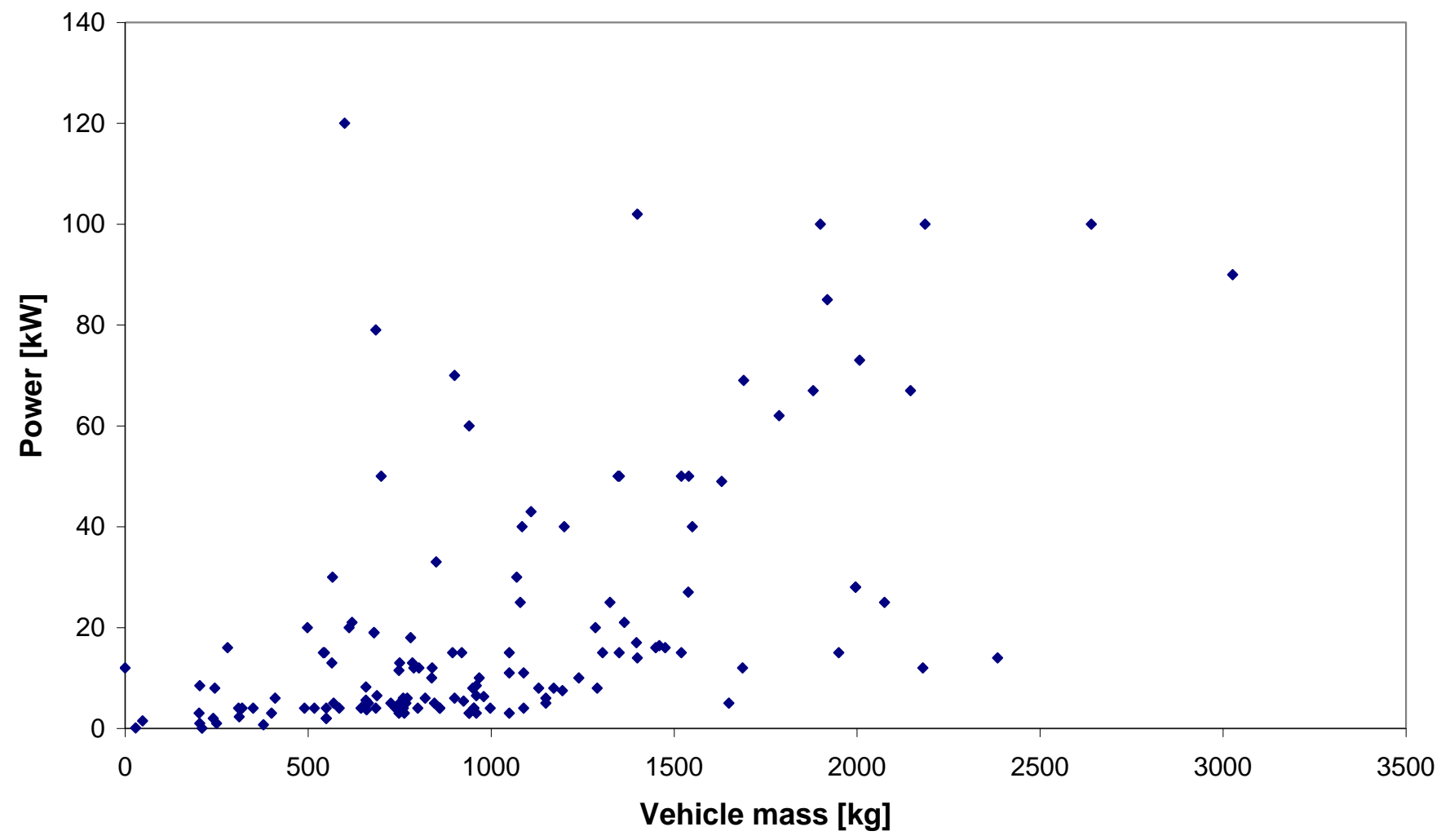

Figure 16 -Relation between the continuous power and vehicle mass.

In terms of motoring, a new trend exists on full electric vehicles, which is the integration of the motor on the wheel hub. Just 28 vehicles with electric traction have their motors "in-the-wheel", either on two or on the four wheels, and one example was found with eight wheels with its one motor, the Eliica from Japan. This type of power transmission configuration has a significant benefit on saving mechanical losses from the electric motor to the wheel. On this kind of devices, the motor is built in the wheel and on this module may also be integrated the suspension and steering. This design solution also allows design teams to rethink the vehicle layout, as more space is free within the vehicle, once all moving parts are placed on or near the wheel.

\section{SUMMARY/CONCLUSIONS}

A computer database was created using MS Access and information of technical specifications of electric and hybrid vehicle models was stored. Vehicle models were classified on categories concerning several criteria, namely vehicle type, powertrain configuration and status of development.

This database of vehicle model information allowed for the definition of several queries relating data from the vehicle and its powertrain components such as batteries, electric motors and internal combustion engines.

The data collected revealed that on the electric mobility industry the most common vehicle model configuration is the conventional sedan and SUV, followed by NEVs and microcars. In terms of status of development nearly $50 \%$ of all vehicles launched did not get into the market revealing a lack of maturity of the electric/hybrid technology.

Page 24 of 26 
For each vehicle type an analysis was made describing the average powertrain characteristics such as battery pack type and capacity, motor type and power and internal combustion engine type and other features. The same type of analysis was made for each powertrain type. A deeper analysis was made to the battery packs and motors. This analysis allowed to determine some average relations between battery power, vehicle weight and range, as well as relations between motors power, vehicle mass and acceleration.

\section{REFERENCES}

1. Mayor of London “An Electric Vehicle Delivery Plan for London”, May 2009, http://www.london.gov.uk/mayor/publications/2009/docs/electric-vehicles-plan.pdf, last access 16 of September 2009.

2. "Powertrain 2020 China's Ambition to Become Market Leader in E-Vehicles", Roland Berger Strategy Consultants, Munich/Shanghai, April, 2009.

3. SAE J1715 Information Report, Hybrid Vehicle (HEV) and Electric Vehicle Terminology, July 2007.

4. Tate, E. D., Harpster, M. O., Savagian, P. J., "The Electrification of the Automobile: From the Conventional Hybrid, to Plug-in Hybrids, to Extended Range Electric Vehicles”, SAE 2008-01-0458, 2008.

5. Chu, A., "The Use of A123 Systems Technology in PHEV Applications", PHEV2007 Conference, Winnipeg, Canada, November 1-2, 2007.

6. Burke., A., Miller, M., "Performance Characteristics of Lithium-ion Batteries of Various Chemistries for Plug-in Hybrid Vehicles", EVS24, Stavanger, Norway, May 13-16, 2009.

7. Signorelli, R., Schindall, J., Kassakian, J., "Carbon Nanotube Enhanced Double Layer Capacitor", Proceedings of the 14th intern. Seminar on Double Layer Capacitors and Hybrid Energy Storage Devices, FL, USA, p. 49-61, December 6-8, 2004.

8. Chau, K. T., Wong, Y. S., Chan, C. C., “An Overview of Energy Sources for Electric Vehicles”, Energy Conversion \& Management 40 (1999) 1021-1039.

9. Brockbank, C., Cross, D., "Mechanical Hybrid System Comprising a Flywheel and CVT for Motorsport \& Mainstream Automotive Applications", SAE 2009-01-1312, 2009.

10. Rahman, K.M., Patel, N. R., Ward, T. G., Nagashima, J. M., Caricchi, F., Crescimbini, F., “Application of Direct-Drive Wheel Motor for Fuel Cell Electric and Hybrid Electric Vehicle Propulsion System”, IEEE Transactions on Industry Applications, Vol. 42, NO. 5, September/October 2006.

11. Ribeiro, B., Martins, J., "Direct Comparison of an Engine Working under Otto, Miller and Diesel cycles: Thermodynamic Analysis and Real Engine Performance”, SAE 2007-01-0261, 2007.

12. “AVL Range Extender”, http://www.avl.com/emag/Range_Extender/ last access 21 of September 2009.

13. "Lotus Range Extender Engine Revealed", Lotus Press release, 07 September 2009.

14. “Toyota Hybrid System THS II”, Toyota Motor Corporation, Tokyo, May 2003.

15. Abe, S., Murata, M., "Development of IMA Motor for 2006 Civic Hybrid”, SAE 2006-01-1505, 2006.

16. http://automobiles.honda.com/fcx-clarity/ last access 21 of September 2009.

17. Bowers, B. J., et al., "Multi-Fuel Fuel Processor and PEM Fuel Cell System for Vehicles", SAE 2007-010692, 2007.

18. "Renault-Nissan Alliance Takes Initial Zero Emission Mobility Move in Europe", Nissan Press release, 20 July 2009.

\section{CONTACT INFORMATION}

Bernardo Ribeiro is a Post-Doctoral researcher at the Universidade do Minho, Portugal. He can be contacted through bernardor@dem.uminho.pt. 
Francisco P. Brito is a Post-Doctoral researcher at the Universidade do Minho, Portugal. He can be contacted through francisco@dem.uminho.pt

Jorge Martins is an Associate Professor at the Universidade do Minho at Guimaraes, Portugal, where he is head of the I.C. Engines Laboratory. He can be contacted through jmartins@ dem.uminho.pt

\section{ACKNOWLEDGMENTS}

Bernardo Ribeiro thanks the FCT and MIT Portugal Program for the financial support given for his research activities (SFRH / BPD / 48189 / 2008).

This research project was supported by MIT-Pt/EDAM-SMS/0030/2008.

\section{DEFINITIONS/ABBREVIATIONS}

EV - Electric Vehicle

ICE - Internal Combustion Engine

LIVC - Late Intake Valve Closure

MPV - Multi-Purpose Vehicle

NEV - Neighborhood Electric Vehicle

OEM - Original Equipment Manufacturer

PEM - Proton Exchange Membrane

PV - PhotoVoltaic

SUV - Sport Utility Vehicle

VVT - Variable Valve Timing 